\title{
The Analysis of Young Entrepreneurs' Performance in the Milkfish Presto MSMEs in Semarang, Indonesia
}

\author{
Moch Norrochim Mashuri \\ Development Economics Studies, \\ Faculty of Economics and Business \\ Diponegoro University \\ Semarang, Indonesia
}

\begin{abstract}
The Micro, Small and Medium Enterprises (MSMEs) of milkfish presto in Semarang have decreased in terms of quantity and quality. The problems faced are the low levels of productivity due to the internal factors, such as: the quality of Human Resources, limited information on access to capital, innovation, and business networking capabilities; and the external factors, such as: high transaction costs, scarcity of raw materials, the acquisition of formal legality and government policies,. This study raised the prestige of milkfish MSMEs in Semarang because it continued to experience a decline from 2013-2019, amounting to $48.64 \%$ due to these internal and external factors. Therefore, the aims of this study is to analyze the effect of labor, business capital, innovation, government policy, and networking capabilities on the performance of young entrepreneurs at milkfish presto MSMEs in Semarang. The source data is used by the collection of questionnaires from 41 respondents of the milkfish presto MSME owners in Semarang. The analytical method using multiple regression by SPSS 21 analysis tools. The results showed that business capital, innovation, government policies, and networking capabilities significantly influence the performance of young entrepreneurs, and labor does not significantly influence the performance of young entrepreneurs. The conclusion of this study is that to improve the performance of young entrepreneurs, it is necessary to encourage increased business capital, innovation, and government policies, as well as networking capabilities
\end{abstract}

Keywords:- Labor; Business Capital; Innovation; Government Policy; Network Capability; Performance of Young Entrepreneurs)

\section{INTRODUCTION}

Micro, Small and Medium Enterprises (MSMEs) face challenges in the era of economic globalization and trade liberalization which is developing rapidly and with a rapid rate of technological progress. MSMEs are required to carry out productive, efficient production processes and produce products that are in accordance with the frequency of the global market with high standards. In Central Java MSMEs show the growth and development of products, both in the type, design, and raw materials created from the creativity and innovation of business people in region.

\author{
Purbayu Budi Santosa \\ Development Economics Studies, \\ Faculty of Economics and Business \\ Diponegoro University \\ Semarang, Indonesia
}

One of the UMKM in Central Java is a UMKM which is engaged in presto milkfish. Central Java is included in the three big milkfish commodity producers, because it is widely used by the community to become processed food that has high selling value (Department of Maritime Affairs and Fisheries, 2018). The number of presto milkfish processors in Central Java in general and the city of Semarang in particular, make business competition even tougher. This business becomes a viable business option to be run based on the Semarang city fisheries service data in 2018 that the city of Semarang has a potential for milkfish presto seen from a total production of 1,016 tons with a total value of IDR 2,364,783,300.

Semarang city government has established a cluster program in this prestigious milkfish business with the aim of making the iconic superior product in the city and improving the living standards of the business people. This program originated from the FEDEP (Forum for Economic Development and Employment Promotion) by taking a cluster approach to economic empowerment, reducing the difference between achievement plans and reality on the ground.

The classic problems faced by MSMEs are low productivity, this situation is caused by internal problems faced by MSMEs namely: the low quality of Human Resources (HR) in management and the limited information of MSMEs on access to capital, business networks, and innovation. External problems faced by MSMEs include the high transaction costs due to unfavorable business climate, scarcity of raw materials, technology, government policies as well as the acquisition of formal legality which is still a fundamental problem for MSMEs in Indonesia.

Cabral et al., (2015) states that the factors that determine the capability of a business network are innovation. Innovation, which is one of the three dimensions of entrepreneurial orientation, is closely related to the ability to apply creativity in order to solve problems and opportunities to improve and enrich life. Sumantri et al, (2013) show that the external environment on government policy variables and personal characteristics / labor have a positive and significant results to business performance, but innovation in entrepreneurship have a negative and significant result to business performance. The research of Ferdinand and Fitriani (2015) showed a significant positive 
effect on innovation to iconic product and in the end have a significant positive effect on the marketing performance. Chen et al., (2008); and Cabral et al., (2015) showed a significant positive effect between innovation on the performance of entrepreneurs. The research of Bengesi and Roux, (2014) networking capability factors include internal communication, partners knowledge, relational skill, and coordination showed a positive effect on SME performance. Narendracista and Yasa (2018) in the variables labor showed significant positive results while Business capital has a positive effect on industry performance metal craft household goods in the village.

The problem that arises is based on the phenomenon gap, where the number of Presto milkfish MSMEs in Semarang in 2013-2019 continues to decline. The problem in this study is also supported by the results of the development of the number of presto milkfish cluster MSM clusters, so the question that must be answered in this study is whether labor, business capital, innovation, government policy, and network capabilities affect the performance of young entrepreneurs.

\section{LITERATURE REVIEW}

\section{A. Performance of Young Entrepreneurs}

The performance of young entrepreneurs is the ability of organizations run by youth to transform themselves in facing challenges from the environment with a long-term perspective. Performance appraisal is part of the company's efforts to see the suitability of the strategies adopted in dealing with environmental changes. The environment has indeed become an important part of the company and things that are difficult for the company to change. The company can only recognize and then manage it well so that it can get the benefits. The introduction of a good environment will have an impact on the quality of the resulting strategy which in turn will have an impact on the performance of entrepreneurs.

The performance of entrepreneurs as a result of implementing corporate strategies, including good customer satisfaction, new product success, increased sales, and company profitability. Meanwhile, Voss and Voss (2000) define entrepreneurial performance as an effort to measure the level of performance which includes sales turnover, number of customers, profits and sales growth. Referring to the definition of entrepreneurial performance, the indicators used to measure entrepreneurial performance include sales turnover, number of customers, profits and sales growth.

\section{B. Labor}

Labor is a group of working age population who are able to work or carry out economic activities in producing goods and services to meet the needs of the community. Labor is a very important factor and is considered in the production process and in sufficient quantities, not only seen from its availability but quality and kinds.
Human resources play an important role in every organization of industrial activities, although the role and function of labor has been largely replaced by industrial machines, but in reality labor is still an important factor in determining the course of the production process. Every small industry wants every workforce to work effectively and efficiently so that it becomes a professional workforce, has the skills and abilities, so that they are able to work more productively and are able to meet production targets.

Production activities with enough manpower will be quickly resolved. If the workforce is well educated, the business will work more productively and the production results obtained will be in accordance with the specified targets. The workforce factor is always improved in ability or skills through both formal and non-formal education. Labor is an important factor in the survival of the industrial sector. A production process will not run smoothly without labor in it.

The research Narendracista and Yasa (2018) in the variable labor showed significant positive on industry performance metal craft household goods in the village, and Sarwanti, Aprilliyanti, et al. (2017) which states that labor does not significantly influence the performance of tofu industry entrepreneurs in Sukoharjo regency.

According to this, we propose the following hypothesis: Hypothesis 1. Labor positively influences Young Entrepreneurs' Performance in the Milkfish Presto MSMEs in Semarang.

\section{Business Capital}

Every company needs to provide business capital to carry out day to day operations, for example to buy raw materials, pay employee wages, and other costs. Some of the funds spent to finance the company's operations are expected to re-enter the company again in the short term through the sale of merchandise or production results. The money that comes from the sale of the merchandise will be re-issued to finance the company's subsequent operations.

The money or funds will continue to revolve continuously for each period during the business operation. Understanding the meaning of venture capital is closely related to the calculation of venture capital requirements. Different understanding of venture capital will lead to the calculation of different business capital requirements as well. Business capital is all current assets owned by a company or can also be intended as funds that must be available to finance the company's daily operations. Business capital is a company's investment in short-term assets. Business capital can also be considered as funds available to invest in non-current assets or to pay noncurrent debt.

The need for venture capital is absolutely provided by the company in any form. That to meet these needs requires sources of venture capital that can be sought from various available sources. The choice of capital source needs to be considered in terms of the loss and loss of the source of 
capital. This consideration needs to be done so as not to burden the company in the future or it will cause unwanted problems.

The research Narendracista and Yasa (2018) in the variables business capital has a positive effect effect on industry performance metal craft household goods in the village. And Winarsih, et al (2014) capital has a significant partial effect in increasing production in the salt processing industry in Pati Regency and the research Imadudin, Zaki et al (2014) in capital structure on entrepreneur performance the result shows has impact positive but not significant

According to this, we propose the following hypothesis: Hypothesis 2. Business Capital positively influences Young Entrepreneurs' Performance in the Milkfish Presto MSMEs in Semarang.

\section{Innovation}

Innovation is an idea, practice or object that is considered new by an individual or other user unit, that innovation is the ability to apply creativity in order to solve problems and opportunities to improve and enrich life.

A company's ability to use new organizational forms and processes can enhance its ability to look for new opportunities internally, such as technological advancements and external things such as new markets or expanding markets. This is what results in entrepreneurial success expressed in Hadayati (2012) research.

Entrepreneurial business which is described through its capacity to make future plans, its capacity to innovate and willingness to take risks, will facilitate it to innovate, and also develop and grow successfully. Innovation is a key characteristic of an entrepreneurial business that affects the performance of entrepreneurs.

Innovation is very important due to the following reasons: (1) technology changes very rapidly as new products, processes and new services from competitors, and this encourages entrepreneurial efforts to compete and succeed. What must be done is to adjust to new technological innovations; (2) the effect of environmental changes on product life cycles is getting shorter, which means that old products or services must be replaced with new ones quickly, and this can happen because there are creative thoughts that lead to innovation; (3) consumers today are smarter, group focused and demanding. They expect more in terms of quality, renewal, and price. Innovative skills are therefore needed to satisfy the needs of consumers while maintaining them; (4) with markets and technology changing very fast, truly good ideas can be increasingly easily copied, and this requires methods of using products, new and better processes, and continually faster services; (5) innovation can result in faster growth, increase market segments, and create a better corporate position.
The research Ferdinand and Fitriani (2015) showed a significant positive effect on innovation to iconic product and in the end have a significant positive effect on the marketing performance. Chen et al., (2008); and Cabral et al., (2015) showed a significant positive effect between innovation on the performance of entrepreneurs. Rosli, M.M et al., (2013) showed a significant positive effect on the Performance of Small and Medium Manufacturing Enterprises, and based on Ch, Irwan, et al (2020) stated innovation has negative impact of financial performance in the micro, small and medium business due to innovation requires cost.

According to this, we propose the following hypothesis: Hypothesis 3. Innovation positively influences Young Entrepreneurs' Performance in the Milkfish Presto MSMEs in Semarang.

\section{E. Government Policy}

The government has the authority to provide direction for community activities, therefore the government has the right to make rules and regulations for the benefit of the community. Government policy is a series of actions / activities that are submitted to a person, group or government in a certain environment where there are obstacles (difficulties) and possibilities (opportunities) where the policy is suggested to be useful to achieve an expected goal.

The government is leading the formation, sponsorship and administration of most supporting programs, especially in developing countries, the government related to entrepreneurship will greatly help ensure sustainability and positive entrepreneurial practices. As such, it will bring economic development through SME development, job creation and wealth creation. A number of studies have been conducted regarding the role of government policy in developing entrepreneurship in general and its impact on economic development. Policies map a course and provide guidelines for implementing government programs. This guides the government's thinking in implementing the program and determining its direction. One example is government and administration which are fundamentally based on policies made by the government, often these policies can be achieved on paper, however, there are always problems with implementing these policies due to several governance factors and a strong willingness to achieve them.

The research conducted by Munizu (2010) stating that government policies have a positive and significant influence on the performance of micro and small businesses in South Sulawesi research Sumantri et al ( 2013) on the external environment covers aspects of government policy in women's entrepreneurial business performance:, where the influence of the external environment on entrepreneurship is positive and significant and Obaji and Olugu (2014) with the level of entrepreneurial performance influenced by government policy through development programs in the fields of fiscal policy, training, finance and equipment grants, and capital in improving the performance 
of entrepreneurs. The research Sandra et al., (2015) government policy variables on external factors show insignificant positive results.

According to this, we propose the following hypothesis: Hypothesis 4. Government Policy positively influences Young Entrepreneurs' Performance in the Milkfish Presto MSMEs in Semarang.

\section{F. Networking Capabilities}

Sijabat (2009) in the Indonesian marketing science journal defines networking capability as "the ability to build integrated cooperation between two or more parties, which is harmonious, synergistic, systematic, integrated and aims to unite business potential in generating optimal profits".

A network, which is implied as an act in contact with other people and organizations, can also be classified as human resources and networking is an alternative to using internal resources. Networking is a variable that is considered important for all types of companies, especially with regard to the fact that the economic environment is becoming increasingly competitive. Networks are becoming increasingly important because they make it easier for companies to access information, resources, markets and technology (Gulati, et al, 2000: 205). Information and social networks (social networks) are considered important for the formation of companies and for the success and sustainability of the company. Although all companies take part in formal and informal networks, larger companies are more likely to make long-term cooperation contracts, while smaller companies, entrepreneurial companies tend to involve themselves in more personal contracts and more mutually beneficial (reciprocal). Technological learning and various other types of organizational learning can take place in informal network or formal networks. Some resources such as communicative and open environment and information flow can enrich the innovation process in an organization.

The research of Bengesi and Roux, (2014) networking capability factors include internal communication, partners knowledge, relational skill, and coordination showed a positive effect on SME performance and Lukiastuti, Fitri (2016) in capability networking on SME performance factors show insignificant positive results.

According to this, we propose the following hypothesis: Hypothesis 5. Networking Capabilities positively influences Young Entrepreneurs' Performance in the Milkfish Presto MSMEs in Semarang.

\section{RESEARCH METHOD}

This research was conducted to test the hypothesis, with the intention of providing reinforcement of the hypothesis formulated with the expectations of supporting and strengthening the theory used as a starting point for thinking.

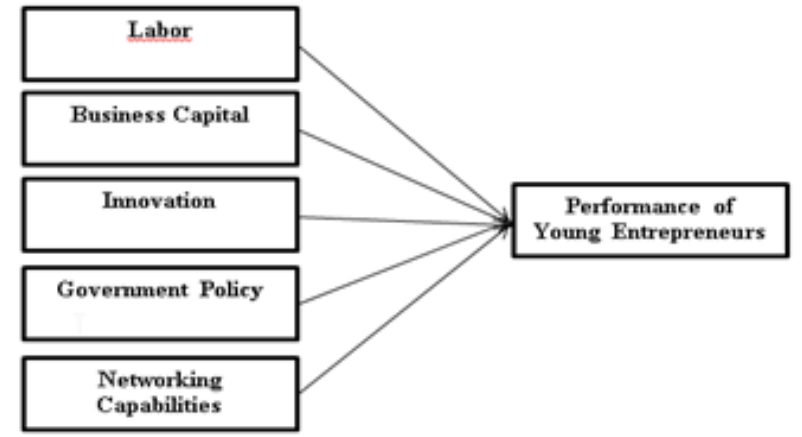

Figure 1: Research Framework

This type of research uses "Explanatory Research", or research that aims to get as much and broadest information as possible on research objects that are not yet widely known. This means that this research is useful to provide information in outline, or as a first step for more in-depth research (Ghozali, 2015).

\section{A. Data Collection Technique}

The research method of data in this study is to use interviews and questionnaires using the Likert scale given to a series of alternatives in the questionnaire is the summed rating method. The population used in this study was the MSMEs cluster of young entrepreneurs in Semarang, amounting to 41 respondents based on data from the Department of Cooperatives and MSMEs. Sample collection uses nonprobability sampling technique with saturated sample type in which the population is less than 100 respondents, so the sample data used are 41 young entrepreneurs, because 41 respondents have represented as samples with age range of 16-30 years.

\section{B. Result and Discussion}

The analysis used in this research is quantitative data research using linear regression statistical equipment, the data that has been available is processed using tools such as SPSS (Statistical Package for Social Science) versi 21.00 for Windows statistical data processing program. The results obtained will be displayed instantly, this is done to be able to reduce the error rate both human error and machine error in the analysis process. Regression Analysis is used, to see the effect of the independent variables on the dependent variable together or to determine the coefficient of determination and correlation coefficient and other measuring tools, the available data will be analyzed using a linear regression analysis tool in the SPSS program. The summary of the results of the regression analysis can be seen in Table 1.

\begin{tabular}{lccc}
\hline & $\mathrm{N}$ & Mean & Std. Dev \\
\hline Labor & 41 & 19.71 & 3.737 \\
Business Capital & 41 & 14.22 & 2.743 \\
Innovation & 41 & 23.76 & 4.134 \\
Govermment Policy & 41 & 19.56 & 3.557 \\
Networking Capability & 41 & 15.71 & 3.296 \\
Performance of Young Entreprs & 41 & 20.98 & 3.205 \\
\hline
\end{tabular}

Table 1:- Descriptive Statistics 
It can be seen that the dependent variable $Y$ (Performance of Young Entrepreneurs) has an average of 20.98 with a standard deviation of 3,205 , while for the independent variable X1 (Labor) has an average of 19.71 with a standard deviation of 3737 , the independent variable X2 (Business Capital) has an average of 14.22 with a standard deviation of 2.743 , the independent variable X3 (Innovation) has an average of 23.76 with a standard deviation of 4.134, an independent variable X4 (Government Policy) has an average of 19.56 with a standard deviation of 3,557 and independent variable X5 (Network Capability) has an average of 15.71 with a standard deviation of 3.296. Furthermore, to answer the research problem can be seen in Table 2 summary of the $\mathrm{R}$ Square model.

\begin{tabular}{ccccc}
\hline Model & R & R Square & $\begin{array}{c}\text { Adjusted R } \\
\text { Square }\end{array}$ & $\begin{array}{c}\text { Std. Error of the } \\
\text { Estimate }\end{array}$ \\
\hline 1 & $.914^{2}$ & .835 & .811 & 1.393 \\
\hline $\begin{array}{l}\text { a) Predictors } \\
\text { Business Capital, Government Policy, } \\
\text { Table 2:- R Square Model Summary }\end{array}$
\end{tabular}

Shows the correlation value 0.914 and the coefficient of determination $0.835(83.5 \%)$. These results illustrate the relationship of variables $\mathrm{X} 1, \mathrm{X} 2, \mathrm{X} 3, \mathrm{X} 4, \mathrm{X} 5$ to $\mathrm{Y}$ (Performance of Young Entrepreneurs) classified very closely. The influence described by X1, X2, X3, X4, X5 on $\mathrm{Y}$ was $83.5 \%$ with the remaining $16.5 \%$ outside the model.

From the ANOVA Table 3, F value of 35,342 was obtained with a probability value (sig.) $=0,000$. Because the value of sig. $<0.05$, the hypothesis is accepted, which means that together with the Performance of Young Entrepreneurs, Labor, Business Capital, Innovation, Government Policy, Network Capability simultaneously influence.

\begin{tabular}{rlrrrrr}
\hline & Model & Sum of Squares & df & Mean Square & F & \multicolumn{1}{c}{ Sig. } \\
\hline \multirow{4}{*}{1} & Regression & 343.033 & 5 & 68.607 & 35.342 & $.000^{\circ}$ \\
\cline { 2 - 5 } & Residual & 67.942 & 35 & 1.941 & & \\
& Total & 410.976 & 40 & & & \\
\hline
\end{tabular}

Table 3:- Regression Linier Test - ANOVA

a)Dependent Variable: Performance of Young

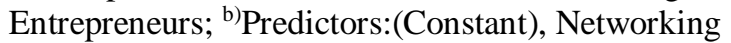
Capability, Labor, Business Capital, Government Policy, Innovation

\begin{tabular}{|c|c|c|c|c|c|c|}
\hline & \multirow[t]{2}{*}{ Model } & \multicolumn{2}{|c|}{ Unstandardized Coefficients } & \multirow{2}{*}{$\begin{array}{c}\begin{array}{c}\text { Standardized } \\
\text { Coefficients }\end{array} \\
\text { Beta }\end{array}$} & \multirow[t]{2}{*}{$t$} & \multirow[t]{2}{*}{ Sig. } \\
\hline & & B & Std. Error & & & \\
\hline \multirow{6}{*}{1} & (Constant) & 2.342 & 1.441 & & 1.626 & .113 \\
\hline & Labor & .059 & .089 & .069 & .665 & .510 \\
\hline & Business Capital & .270 & .126 & .231 & 2.138 & .040 \\
\hline & Innovation & .214 & .098 & .276 & 2.180 & .036 \\
\hline & Govemment Policy & .258 & .113 & .286 & 2.280 & .029 \\
\hline & Networking Capability & .222 & .096 & .229 & 2.325 & .026 \\
\hline
\end{tabular}

Table 4:- Regression Linier Test

\author{
a)Dependent Variable : Performance of Young \\ Entrepreneurs
}

Table 4 shows that there is no effect of Labor on Performance of Young Entrepreneurs because the sig value is $0.510>0.05$. Business Capital, Innovation, Government Policy, Network Capability have effect on Performance of Young Entrepreneurs because the sig value is $<0.05$. Based on Table 4, it can be concluded that the formed regression equation is :

\section{$Y=2,342+0,059 X_{1}+0,270 X_{2}+0,214 X_{3}+0,258 X_{4}+$ $0,222 \mathrm{X}_{5}$}

The regression equation has the following meanings: (1) Constants $=2,342$, if the variable of labor, business capital, innovation, government policy and network capability are assumed to be fixed then perfomance of young entrepreneurs will be 2,342. (2) Labor coefficient $\left(X_{1}\right)=0.059$, if the labor variable experiences an increase, while business capital, innovation, government policy and fixed network capability, the business performance variable increases by 0.059 . (3) Business capital coefficient $\left(\mathrm{X}_{2}\right)=$ 0,270 , if the business capital variable increases, while labor, innovation, government policy, and fixed network capability, the business performance variable increases by 0.322. (4) The coefficient of innovation $\left(\mathrm{X}_{3}\right)=0.214$, if the innovation variable experiences an increase, while labor, business capital, government policy and network capability remain, then the innovation variable rises by 0.214 . (5) Government policy coefficient $\left(\mathrm{X}_{4}\right)=0.258$, if government policy variables increase, while labor, business capital, innovation, and fixed network capability, then business performance variables increase by 0.258 , (6) Network capability coefficient $\left(\mathrm{X}_{5}\right)=0.222$, if the variable capability of the network increases while the variable labor, business capital, innovation, and government policies remain, then the variable performance of young entrepreneurs increases by 0.222 . After conducting the linear regression test the next step is to test the hypothesis that the partial test ( $\mathrm{t}$ test) and partial test is used to test how far the influence of the independent variables (labor, business capital, innovation, government policy and network capability) partially on the dependent variable (performance young entrepreneurs). If the significant level is less than $5 \%$, then $\mathrm{H} 0$ is rejected and $\mathrm{Ha}$ is accepted. Based on the results of the $\mathrm{t}$ test showed that the significant value for the labor was 0.510 , significant business capital was 0.40 , significant innovation was 0.36 , significant government policy was 0.29 and significant networking capabilities were 0.26 . Based on the regression model above, $\mathrm{H}_{2}, \mathrm{H}_{3}, \mathrm{H}_{4}$, and $\mathrm{H}_{5}$ are accepted while $\mathrm{H}_{1}$ is rejected.

\section{The effect of Labor on the Performance of Young Entrepreneurs}

The results of the regression analysis showed a positive variable labor regression coefficient of 0.059 on the performance of young entrepreneurs. Based on the results of the partial test ( $\mathrm{t}$ test) obtained information that the labor variable has a negative and significant effect on the performance of young entrepreneurs. This is consistent with 
the partial test (t test) which shows a significance value of 0.510 where the value is more than 0.05 , it can be concluded that $\mathrm{H}_{1}$ is rejected. labor in a business is not really needed when the business is being pioneered because the entrepreneur's expertise and ability alone is sufficient to manage the business and adding labor when starting a business will add a separate cost burden for the business. this result is supported by research Sarwanti, Aprilliyanti, et al. (2017) which states that labor does not significantly influence the performance of tofu industry entrepreneurs in Sukoharjo regency.

\section{Effect of Business Capital on the Performance of Young Entrepreneurs}

The results of the regression analysis showed a positive coefficient of business capital regression coefficient of 0.270 to the performance of young entrepreneurs. Based on the results of the partial test ( $\mathrm{t}$ test) obtained information that the venture capital variable has a positive and significant effect on the performance of young entrepreneurs. This is consistent with the partial test (t test) which shows a significance value of 0.40 where the value is less than 0.05 , it can be concluded that $\mathrm{H}_{2}$ is accepted. Business capital that is available in large quantities will also have a large influence on smoothing the business so that business performance can be optimized. Thus, business capital has a strategic position in developing business that is being run, this is in line with the research of Narendracista and Yasa's research (2018) in the variable business capital has a positive effect effect on the performance industry of metal craft household goods in the village of packaging . And Winarsih, et al (2014) stated that capital has a significant partial effect in increasing production in the salt processing industry in Pati Regency.

\section{E. The effect of Innovation on the Performance of Young Entrepreneurs}

The results of the regression analysis showed a positive variable innovation regression coefficient of 0.214 on the performance of young entrepreneurs. Based on the results of partial tests ( $t$ test) obtained information that the innovation variable has a positive and significant effect on the performance of young entrepreneurs. This is consistent with the partial test ( $\mathrm{t}$ test) which shows a significance value of 0.36 where the value is less than 0.05 , it can be concluded that $\mathrm{H}_{3}$ is accepted. more and more innovations made on products, packaging and marketing will increase the business that is being run and increase profits and business revenues. in line with research Ferdinand and Fitriani (2015) showed a significant positive effect on innovation to iconic products and in the end has a significant positive effect on the marketing performance. Chen et al., (2008); and Cabral et al., (2015) showed a significant positive effect between innovation on the performance of entrepreneurs.

\section{F. The effect of Government Policy on the Performance of Young Entrepreneurs}

The results of the regression analysis showed a positive coefficient regression coefficient of government policy that is 0.258 on the performance of young entrepreneurs. Based on the results of partial tests ( $t$ test) obtained information that the innovation variable has a positive and significant effect on the performance of young entrepreneurs. This is in accordance with the partial test ( $t$ test) which shows a significance value of 0.29 where the value is less than 0.05 , it can be concluded that $\mathrm{H}_{4}$ is accepted. Business performance is the success achieved by a business. The success achieved cannot be separated from environmental influences around. System theory states that the influence of internal and external environment in achieving business performance, one of them External factors here are the government's support. This is supported by research conducted by Munizu (2010) stating that government policies have a positive and significant influence on the performance of micro and small businesses in South Sulawesi. Government policy is one of the drivers for Micro and Small Enterprises (MSEs) to be able to develop their businesses, based on research conducted by Munizu, the efforts carried out by the government include capital access assistance, preparation of business locations, training, and coaching. Preparation of business locations, training, and coaching. Sumantri et al (2013) on the external environment covers aspects of government policy in women's entrepreneurial business performance:, where the influence of the external environment on entrepreneurship is positive and significant and Obaji and Olugu (2014) with the level of entrepreneurial performance influenced by government policy through development programs in the fields of fiscal policy, training, finance and equipment grants, and capital in improving the performance of entrepreneurs.

\section{G. Effect of Network Capabilities on the Performance of Young Entrepreneurs}

The results of the regression analysis showed a positive coefficient regression coefficient of the networking capability of 0.222 to the performance of young entrepreneurs. Based on the results of partial tests ( $t$ test) obtained information that the innovation variable has a positive and significant effect on the performance of young entrepreneurs. This is consistent with the partial test ( $\mathrm{t}$ test) which shows a significance value of 0.26 where the value is less than 0.05 , it can be concluded that $\mathrm{H}_{5}$ is accepted. more networks owned by an entrepreneur will improve business performance because it makes it easier to distribute products and raw materials so that Santa's network capability is needed in an entrepreneur's performance, and this research is in line with The research of Bengesi and Roux, (2014) networking capability factors include internal communication, partners' knowledge, relational skills, and coordination showed a positive effect on SME performance. 


\section{CONCLUSIONS, SUGGESTIONS AND LIMITATIONS}

Based on the results of data analysis and discussion, the following conclusions are : (1) Labor has a negative influence on the performance of young entrepreneurs, so that in running a presto milkfish business there is no need to involve human resources (employees) directly in the performance of entrepreneurs; (2) Business capital has a positive and significant effect on the performance of young entrepreneurs. In building a business and improving the performance of young entrepreneurs, the main factor is business capital to support the success of the performance of young entrepreneurs in order to continue to exist for many years and to meet the daily supply of raw materials; (3) Innovation has a positive and significant effect on the performance of young entrepreneurs and thus in improving the performance of entrepreneurs is balanced with an innovation strategy to realize a growing performance; (4) Government policy has a positive and significant effect on the performance of young entrepreneurs. Government policy programs expected to encourage the progress of young entrepreneurs in the taxation sector and the development of MSMEs especially with the FEDEP (Forum for Economic Development and Employment Promotion) in Semarang, it is expected to advance the prestige milkfish MSME sector; (5) Network capability has a positive and significant effect to the development of young entrepreneurs performance, the existence of networking capabilities owned by milkfish Presto MSMEs can synergize with each other in running and advancing among interrelated entrepreneurs.

The limitations of this study is that we were only focusing on young entrepreneurs of milkfish Presto MSMEs in Semarang. There are many factors that affect the performance of young entrepreneurs milkfish Presto in Semarang, but the limitations are the authors only use five independent variables. To get broader results, further research can develop research sites with a more diverse MSME sector as well as other variables social capital, technology, behavior, and raw materials.

\section{ACKNOWLEDGMENT}

We would like to thank the Milkfish Presto MSMEs in Semarang for being willing to answer the questionnaire. We also thank the Fisheries Department, and Department of Cooperatives and Micro Small-Medium Enterprises (MSME) in Semarang.

\section{REFERENCES}

[1]. Baumol, William J. (1952). Welfare Economics and the Theory of the State. London: London School of Economics and Political Science, Longmans, Green.

[2]. Bengesi, Kenneth, M.K and Roux, Ingrid Le. (2014). The Influence of Dimensions of Networking Capability in Small and Medium enterprise Perfomance. Journal of Business and Social Science. Vol.5 (2), February 2014.
[3]. Cabral, Jose Ednilson De Oliveira, Arnaldo, Filipe \& Maria. (2015). Capabilities, Innovation, And Overall Performance In Brazilian Export Firm. RAM, Rev. Adm. Mackenzie. Vol.16 (3), May/June 2015.

[4]. Ch, Irwan, Andari, T T, Mukmin, M N. (2020). Analysis Of The Effect Of Corporate and Market Orientation and Innovation On The Productive Economic Perfomance Of The Joint Business Group (UEB KUBE) in the Bukittinggi City of West Sumatera. Jurnal Sosial Humaniora. Vol. 11 (1), April 2020, 40-52.

[5]. Chen, Lu-Jui; Chun-Chung Chen and Wen-Ruey Lee. (2008). Strategic Capabilities, Innovation Intensity, and Performance of Service Firms. Journal of Service and Management. Vol 1, August 2008, 111-122.

[6]. Ferdinand; Augusty Tae dan Lili Karmela Fitriani. (2015). Acculturative Iconic Product Attractiveness And Marketing Perfomance. Journal of Global Strategic Management. Vol.9 (2), Desember 2015, 15 23.

[7]. Ghozali, Imam. (2015). Analisis Multivariate dengan Program SPSS. Semarang: Badan Penerbit Universitas Diponegoro.

[8]. Gulati, R., Nohria N., \& Zaheer A. (2000). Strategic Networks. Strategic Management Journal. Vol. 21 (3), 2000, 203-216.

[9]. Hadayati, Ernani. (2012). Kreativitas dan Inovasi Pengaruhnya terhadap Pemasaran Kewirausahaan pada Usaha Kecil. Jurnal Inovasi dan Kewirausahaan. Vol. I (3), 2012, 135-151.

[10]. Imadudin, Zaki., Swandri, Fifi., \& Redawati (2014). Pengaruh Struktur Modal Terhadap Kinerja Perusahaan. Jurnal Wawasan Manajemen. Vol.2 (1); February 2014, 81-96.

[11]. Lukiastuti, Fitri. (2011). Pengaruh Orientasi Wirausaha Dan Kapabilitas Jejaring Usaha terhadap Peningkatan Kinerja UKM dengan Komitmen Perilaku sebagai Variabel Interviening (Studi Empiris pada Sentra UK-M Batik di Sragen, Jawa Tengah). Jurnal Organisasi dan Manajemen. Vol. 8 (2), 2012, 155-175.

[12]. Munizu, Musran. (2010). Pengaruh Faktor-Faktor Eksternal dan Internal Terhadap Kinerja Usaha Mikro dan Kecil (UMK) di Sulawesi Selatan.Jurnal Manajemen dan Kewirausahaan, Volume 12 No. 12. Hal 33- 41 Makasaran: Universitas Hasanudin.

[13]. Narendracista, I Dewa, Gede \& Yasa, I Gusti, Wayan . (2018). Pengaruh Modal, Tenaga Kerja Dan Teknologi Terhadap Kinerja Industri Kerajinan Barang Logam Di Desa Kamasan E-Jurnal Ekonomi Pembangunan Universitas Udayana. Vol. 7 (7) Juli 2018. 1501- 1529

[14]. Obaji, N. O., \& Olugu, M. U. (2014). The role of government policy in entrepreneurship development. Science Journal of Business and Management. Vol. 2(4), 109-115.

[15]. Rosli, M. M., \& Sidek, S. (2013). The Impact of Innovation on the Performance of Small and Medium Manufacturing Enterprises:: Evidence from Malaysia. Journal of Innovation Management in Small \& Medium Enterprises, 2013, 1. 
[16]. Sandra, Alex. dan Edi Purwanto. (2015). Pengaruh Faktor-Faktor-Eksternal dan Internal Terhadap Kinerja Usaha Kecil dan Menengah di Jakarta. Business Management Journal. Vol. 11(1), Maret 2015, 97-123.

[17]. Sarawanti, Aprilliyanti, Budi, Leonardo, Wulan, Heru S. 2017. Pengaruh Modal Usaha, Biaya Bahan Baku Dan Tenaga Kerja Terhadap Kinerja Usaha Industri Tahu di Kabupaten Sukoharjo. Journal Of Management. Vol 3 (3).

[18]. Schumpeter, A Joseph. (1934). The Theory of Economic Development. Harvard Economic Studies. Available online at https://economicsconcepts.com/schumpeter_model_of _economic_growth.htm. Diakses pada tanggal (21 November 2019).

[19]. Sijabat, R. (2009) Penguatan Kinerja Pemasaran Melalui Pengembangan Inovasi Dan Kreativitas Program Kerja Pada Wirausaha Muda Di Semarang. Jurnal Sains Pemasaran Indonesia (Indonesian Journal Of Marketing Science. Vol 16 (1), 26-42.

[20]. Sumantri, Bayu, Anna Fariyanti, and Ratna Winandi. (2013). "Faktor-faktor yang Berpengaruh terhadap Kinerja Usaha Wirausaha Wanita: Suatu Studi pada Industri Pangan Rumahan di Bogor." Jurnal Manajemen Teknologi. Vol. 12 (3), 2013, 252-277.

[21]. Voss, G. B., dan Voss, Z. G. (2000). Strategic Orientation and Firm Performance in an Artistic Environment. Journal of Marketing. Vol. 64(1), 2000, 67-83.

[22]. Winarsih, Baedhowi, \& Bandi (2014). Pengaruh Tenaga Kerja, Teknologi, dan Modal dalam Meningkatkan Produksi di Industri Pengolahan Garam Kabupaten Pati. Jurnal Pendidikan Insan Mandiri. Vol. 3 (2), 2014, 88-98.

[23]. J. Clerk Maxwell, A Treatise on Electricity and Magnetism, 3rd ed., vol. 2. Oxford: Clarendon, 1892, pp.68-73.

[24]. I.S. Jacobs and C.P. Bean, "Fine particles, thin films and exchange anisotropy," in Magnetism, vol. III, G.T. Rado and H. Suhl, Eds. New York: Academic, 1963, pp. 271-350.

[25]. K. Elissa, "Title of paper if known," unpublished.

[26]. R. Nicole, "Title of paper with only first word capitalized," J. Name Stand. Abbrev., in press.

[27]. Y. Yorozu, M. Hirano, K. Oka, and Y. Tagawa, "Electron spectroscopy studies on magneto-optical media and plastic substrate interface," IEEE Transl. J. Magn. Japan, vol. 2, pp. 740-741, August 1987 [Digests 9th Annual Conf. Magnetics Japan, p. 301, 1982].

[28]. M. Young, The Technical Writer's Handbook. Mill Valley, CA: University Science, 1989. 